\title{
INDEMNIFICATION OF UNDERWRITERS AND SECTION 11 OF THE SECURITIES ACT OF 1933
}

AT common law there was no civil liability to purchasers of securities for negligent misstatements or omissions in the prospectus accompanying the issue. ${ }^{1}$ The Securities Act of 1933 , however, imposed a statutory duty of care upon every person who signs the registration statement for the issue, the directors of the issuer, the "experts" who prepare or certify portions of the registration statement and the prospectus, and the underwriter of the issue. ${ }^{2}$ Civil liability is not confined to misstatements or omissions in information which each party personally supplies; rather, each participant in the issue must discharge the burden of proof that "he had, after reasonable investigation, reasonable ground to believe and did believe," that the entire registration statement and prospectus contained no misstatement or omission. ${ }^{3}$ Though there is no case law to demonstrate the point, it is clear that an underwriter could be held liable for failing to discover a misstatement made by another party to the securities issue.

Under Section 14 of the Securities Act, the underwriter is prohibited from contracting with a securities purchaser for exemption from liability. ${ }^{4}$ But it has become general practice for the original contract between the underwriter and the issuer to contain a provision that each promises to indemnify the other against any liabilities growing out of any act or omission on his part. ${ }^{5}$ In effect, the underwriter vouches only for the information that he provides in the registration statement and prospectus-the price at which the issue is to be offered, the discounts to be allowed sub-underwriters or dealers, and the mode of distribution. ${ }^{6}$ And the underwriter is promised indemnity if he is held liable to a purchaser concerning any information which he did not personally provide. ${ }^{7}$ On its face this arrangement seems fair since each party is held responsible only for his own active misdeeds. But the Securities Act does not impose an absolute statutory liability; the underwriter will only be held liable if, after reasonable investigation, he should have discovered the inaccuracy of the in-

1. Derry v. Peek, 14 App. Cas. 337 (1889); Kountze v. Kennedy, 147 N.Y. 124, 41 N.E. 414 (1895). See Note, The Liability of Directors and Offecrs for Misreprescnlation in the Sale of Securities, 34 CoLum. L. Rev. 1090, 1095-98 (1934).

2. Section 11(a), 48 Stat. 82 (1933), 15 U.S.C. $\$ 77 k$ (a) (1958).

3. Section 11 (b) (3), 48 Stat. $82-83$ (1933), as amended, 15 U.S.C. \$ 77k(b) (3) (1958). This duty is subject to qualifications concerning "expert" statements, Act of June 6, 1934, $\$ 11$ (b) (3) (C), 48 Stat. 907 (1934), 15 U.S.C. $\$ 77 \mathrm{k}(\mathrm{b})(3)$ (C) (1958).

4. Section 14, 48 Stat. 84 (1933), 15 U.S.C. \$ 77n (1958). "Any condition, stipulation or provision binding any person acquiring any security to waive compliance with any provision of this title... shall be void."

5. Thomas, Federal Securities Act Handbook 114 (2d ed. 1960).

6. Lockwood \& Anderson, Underwriting Contracts, within Purvicw of Securities Act of 1933; with Certain Suggested Provisions, 8 Geo. WASr. L. REv. 33, 41 (1939).

7. Practicing Law Institute, When Corporations Go Public 84 (Israels \& Duff eds. 1962). 
formation in the registration statement or prospectus. The indemnity agreement thus relieves the underwriter from the financial consequences of his breach of statutory duty.

The Securities Act does not explicitly deal with indemnity agreements. However, the Securities and Exchange Commission has indicated in Rule 460 that it regards indemnity agreements between the issuer and a "director, officer, or controlling person" of the issuer to be contrary to the act. ${ }^{8}$ In respect to such agreements, the Commission insists that the registration statement contain a clause stating that "in the opinion of the Securities and Exchange Commission such indemnification is against public policy as expressed in the Act" and stating that where a claim for indemnity is asserted (other than for a successful legal defense) the issuer will litigate the validity of the indemnity agreement in the courts. ${ }^{9}$ This rule applies to underwriting contracts only where the underwriter is also a "director, officer, or controlling person" of the issuer. ${ }^{10}$ Otherwise the Commission has expressed no objection to the standard indemnification agreement between issuer and underwriter. ${ }^{11}$ In fact, its lack of concern for underwriter indemnity agreements, when viewed in the light of their widespread use, suggests that the Commission does not question the legality of these agreements.

Professor Loss, however, has raised three objections to indemnity agreements which, if correct, would seem equally applicable both to agreements between the underwriter and the issuer and to those between directors and the issuer.

8. 17 C.F.R. $\S 230.460$ Note (Supp. 1962) :

The Commission ... may refuse to accelerate the effective date: (a) where... provision is made for indemnification by the registrant of a director, officer or controlling person of the registrant against liabilities arising under the act, unless vaiver is obtained from such [indemnitee] ... or there is included in the registration statement ... an undertaking in substanitally [sic] the following form: ... the registrant has been advised that in the opinion of the Securities and Exchange Commission such indemnification is against public policy as expressed in the act and is, therefore, unenforceable. In the event that a claim for indemnification against such liabilities (other than the payment by the registrant of expenses incurred ... in the successiul defense of any action ...) is asserted by such director, officer or controlling person ... the registrant will ... submit to a court of appropriate jurisdiction the question whether such indemnification by it is against public policy as expressed in the act ....

9. Ibid.

10. 17 C.F.R. $\$ 230.460$ Note (Supp. 1962) :

The Commission ... may refuse to accelerate the effective date:

***

(b) Where the underwriting agreement ... contains provisions by which indemnification against liabilities arising under the act are given by the registrant to the underwriter ... and a director, officer or controlling person of the registrant is such an underwriter ... or member of any firm which is such an underwriter unless a waiver or an undertaking of the character specified in paragraph (a) is included in the registration statement.

11. The Chief Counsel of the Commission's Corporation Finance Division stated at a Practicing Law Institute Forum that "it is usual practice to indemnify underwriters, and the Commission is not concerned with the indemnification of undervriters as such." Statement by Charles H. Shreve, in Practicing Law Instrrute, op. cit. supro note 7, at 147. 
He states that Section $11(f){ }^{12}$ which permits contribution among those liable under Section 11 reveals an implicit prohibition of such agreements: "Indemnification defeats pro tanto the statutory provision on contribution."13 But this seems a strained reading of the provision. Arguably, since Section 11(f) permits contribution "as in cases of contract," the right to contribution may be varied by agreement between the entitled parties, ${ }^{14}$ even to full indemnity, as in cases of contract at common law. ${ }^{15}$ Since the clear purpose of Section 11(f) was to supplant the common law rule precluding contribution among joint tortfeasors, ${ }^{16}$ it seems unjustified to read any expression of legislative intention regarding indemnity agreements into Section 11(f).

Loss also suggests that an indemnity agreement might be regarded as a waiver of compliance with the act contrary to Section $14 ; 17$ but Section 14 applies only to agreements "binding any person acquiring any security."18 Although the underwriter himself may properly be regarded as a purchaser acquiring securities from the issuer, his only right under the act against the issuer is for contribution ${ }^{19}$ and that right remains intact. And of course the indemnity agreement does not alter the liability of the underwriter to any later purchaser.

Finally, Loss relies on a prophylactic policy which he regards as implicit in the act, arguing that indemnification "is hostile to the in terrorem effect intended for Section $11 \ldots$ to promote careful adherence to the statutory requirements." ${ }^{20}$ To assess the strength of this argument, we must first determine the content courts have given the notion of public policy in reviewing agreements generally which relieve against the financial consequences of civil liability.

In the leading case of New York Central RR $v$. Lockwood, ${ }^{21}$ which involved an exculpation agreement, the Supreme Court held invalid a contract exempting a railroad from liability to a passenger for any negligent injury. The Court relied on two grounds : exculpation would contradict the purpose of liability in

12. Section $11(\mathrm{f}), 48$ Stat. 83 (1933), 15 U.S.C. $\$ 77 \mathrm{k}(\mathrm{f})$ (1958) :

[E]very person who becomes liable to make any payment under this section may recover contribution as in cases of contract from any person who, if stred separately, would have been liable to make the same payment....

13. 3 Loss, Securrties Regulation 1831 (1961) [hereinafter cited as Loss].

14. See Douglas \& Bates, The Federal Securities Act of 1933, 43 Y ALE L.J. 171, 178-79 (1933).

15. Tait v. Downey, 267 Mass. 422,166 N.E. 857 (1929); Cambria Title Savings \& Trust Co. v. Barron, 293 Pa. 116, 141 Atl. 845 (1928) ; McManus v. Butler, 213 S.W. 447 (Mo. 1919) ; Batard v. Hawes, 2 E1. \& B. 287, 297, 118 Eng. Rep. 775, 778-79 (H.L. 1853) (dictum).

16. 3 Loss 1737.

17. Id. at 1832 .

18. Section 14, 48 Stat. 84 (1933), 15 U.S.C. $\$ 77 \mathrm{n}$ (1958). See text quoted note 4 supra.

19. Section 11(f), 48 Stat. 83 (1933), 15 U.S.C. $\$ 77 \mathrm{k}(\mathrm{f})$ (1958). See text quoted note 12 supra.

20. 3 Loss 1831.

21. 84 U.S. (17 Wall.) 357 (1873). 
"raising the most stringent motive for the exercise of carefulness," and the passenger, who was in a severely inferior bargaining position, would be unfairly deprived of compensation for his injury. ${ }^{23}$

The first ground seems directly applicable to indemnity agreements; accepting the premise that release from financial liability encourages breach of duty, it could be argued that exculpatory agreements and indemnity agreements would produce the same effect. But where indemnity agreements were subsequently challenged under the Lockwood doctrine, the courts refused to accept this objection to these agreements. ${ }^{24}$ Rather such agreements, which involved indemnification for statutory ${ }^{25}$ as well as common law ${ }^{20}$ liability, were upheld, apparently because they were not inconsistent with the second principle expressed in Lockwood: where the injured party was not deprived of compensation, indemnification by a third party would not offend public policy.27

In these cases, where the liability was absolute or for conduct which fell below commonly accepted standards of reasonable care, these courts concluded that the threat of liability would probably not significantly affect the manner of carrying on the activities involved, c.g., management of factories, ${ }^{28}$ railroads, 20 or construction firms. ${ }^{30}$ Moreover, all injured parties may be expected to sue in vindication of their rights. Compensation would effectively undo the harm caused by the negligent conduct; the deterrent value of the threat of liability is too speculative to be determinant of these cases. ${ }^{31}$

But Section 11 of the Securities Act imposed neither strict liability nor liability for conduct which was generally considered to be unreasonable. Rather, it imposed a novel obligation upon those liable, particularly insofar as it required underwriters, accountants, and such experts as engineers and appraisers to make a reasonable investigation into the truth of all information contained in the registration statement and prospectus. The purpose for this new duty is to secure disclosure to the public of as much reliable informa-

22. Id. at 377-78.

23. Id. at 379-80.

24. Private indemnity agreements not involving insurance upheld: General Acc., Fire \& Life Assur. Corp. v. Smith \& Oby Co., 272 F.2d 581 (6th Cir. 1959); Sinclair Ref. Co. v. Stevens, 123 F.2d 186 (8th Cir. 1941), cert. denied, 315 U.S. 804 (1942); Harnden v. Southern Sur. Co., 200 M1o. App. 162, 204 S.W. 34 (1918). Insurance contracts upheld: California Ins. Co. v. Union Compress Co., 133 U.S. 387 (1890) ; Phoenix Ins. Co. v. Erie \& West. Trans. Co., 117 U.S. 312 (1886) ; Trenton Passenger Ry. v. Guarantors' Liab. Indem. Co., 60 N.J.L. 246, 37 At1. 609 (1897). See Annot., 175 A.L.R. 8, at $\$ \$ 14-20$ (1948).

25. E.g., Griffiths \& Son Co. v. National Fireproofing Co., 310 Ill. 331, 141 N.E. 739 (1923).

26. E.g., Kansas City, MI. \& B.R.R. Co. v. Southern Ry. News Co., 151 Mo. 373,52 S.W. 205 (1899).

27. See cases cited notes 24-26 supra \& 28-29 infra.

28. E.g., Cozzi v. Owens Corning Fiber Glass Corp., 63 N.J. Super. 117, 164 A.2d 69 (Super. Ct. App. Div. 1960).

29. E.g., Buckeye Cotton Oil Co. v. Louisville \& N.R.R. Co., 24 F.2d 347 (6th Cir. 1928).

30. E.g., Schwartz v. Merola Bros. Constr. Corp., 290 N.Y. 145, 48 N.E2d 299 (1943).

31. The Am. Cas. Ins. Co. Case, 82 Md. 535, 578, 34 Atl. 778, 786 (1896). 
tion as can be marshaled by all the persons involved in the preparation of a new issue, ${ }^{32}$ on the assumption that many investors unnecessarily lose their capital because they are persuaded to purchase securities about which they have little accurate information. ${ }^{33}$ Because the capability of the Securities and Exchange Commission to discover the truth of statements made is limited, and the accuracy of the information is an essential part of the statutory scheme, the civil liability provisions in effect reinforce the reviewing power of the Commission by requiring that all participants have reasonable grounds to believe in the truth of the information provided. ${ }^{34}$ Furthermore, it is clear that compensation to injured purchasers is not an essential purpose of the act, since it is generally recognized that numerous and widely scattered small stockholders seldom find it worthwhile to bear the expense of the necessarily tortuous litigation required to enforce their claims. 35 Merely to ensure compensation to the few who can afford to demand it would not meet the problem; in fact, the paucity of litigation under Section 11 has borne out this assumption. ${ }^{\text {yo }}$ The act has made the encouragement of investigation and disclosure primary goals in order to prevent misstatements or omissions which would give rise to liability.

Thus the cases upholding indemnity agreements, insofar as they assume that the purposes of civil liability are accomplished if the injured party is compensated, are not applicable in determining the validity of such agreements under the prophylactic policy of the Securities Act. The act contemplates that most statements in a registration statement will be verified separately by several of the participants. ${ }^{37}$ But since the effect of indemnification is to shift all the liability for any given statement to the indemnitor, the likelihood of multiple

32. See H.R. REP. No. 85, 73d Cong., 1st Sess. 2-3 (1933).

33. See, e.g., 78 Cong. Rec. 7704-05 (1934); Note, Publicity and the Sccurity Markat: $A$ Case Study, 7 U. Cri. L. Rev. 676, 680-81 (1940).

34. [T] he provisions for civil liability are calculated to be largely preventive rather than redressive. . . . But even this purpose of securing preventive vigilence . . . is only coordinate with, or probably subordinate to, another object ... [namcly,] to compel the disclosure of significant matters which were heretofore rarely, if ever, disclosed. Civil liability is imposed largely as one appropriate means of accomplishing these ends....

Shulman, Civil Liability and the Securities Act, 43 Y ALE L.J. 227 (1933).

35. [R] egulation in this field is and will remain relatively unimportant from a com* pensatory angle. ... In this connection it should be remembered that man's liabit of sleeping on his legal rights is notorious. ... The truth of this generalization is apparent from the extremely small number of claims actually prosectuted in some of our recent and more notorious scandals.

Douglas \& Bates, stipra note 14, at 216. See Note, 71 YALE L.J. 1341, 1346 (1962).

36. Of some 18,000 registration statements cleared by the Commission, there have been only eleven actions brought under $\$ 11$ and, of these, only two have resulted in atdjudicated recovery. 3 Loss 1690-91.

37. Douglas \& Bates, Some Effects of the Securities Act upon Investment Banking, 1 U. CHr. L. Rev. 283, 291 (1934). The General Counsel of the S.E.C. has referred to "the duty of thorough investigation and analysis imposed by the Act on the underwriter proper." SEC Securities Act Release No. 1862, Dec. 13, 1938, 11 F.R. 10962, 1 CCH FED. SEC. L. REP. $\| 2168.10$. 
verification is decreased. Loss therefore seems correct in suggesting that agreements indemnifying those liable under Section 11 are "hostile to the in terrorem effect of the Act." 38

In view of this conclusion, the Commission's suggestion in Rule 460 that agreements indemnifying directors offend public policy, while those indemnifying underwriters do not, seems unjustifiable. It may be that the basis for Rule 460 is the well established common law rule that agreements indemnifying directors for negligent mismanagement are invalid.30 Such agreements are denied enforcement at common law because they work a "travesty of justice" 10 by requiring, in effect, that stockholders, successful in a derivative suit, must reimburse the unsuccessful director. Thus the stockholders, like the railroad passenger in Lockwood, are deprived of their compensation. Since indemnification for Section 11 liability does not deprive the injured purchaser of his compensation, ${ }^{41}$ however, the rationale of the common law rule lends no support to the Commission's treatment of directors' indemnity agreements as more offensive than underwriters' agreements. Furthermore, the Commission's statement that director's indemnity is against public policy "as expressed in the $A c t$ " is inexplicable; as has been shown, all agreements indemnifying participants in the preparation of a registration statement equally defeat the in terrorem effect of Section 11.

Loss suggests that the difference in the treatment of underwriters and directors in Rule 460 arises from "the fears expressed during the early days of the Act that underwriters would be unwilling to assume the full risks of Section 11. . ."42 But in view of the legislative history, the Commission does not

38. 3 Loss 1831. English public policy supports this reasoning. In 1925, the Court of Appeal upheld an agreement which indemnified an independent auditor held civilly liable for failing to discharge his statutory duty to make a reasonable investigation of company books. In re City Equitable Fire Ins. Co., Ltd., [1925] 1 Ch. 407 (C.A. 1924). Immediately subsequent, a Parliamentary Committee concluded that such agreements allowed the indemuitee "with impunity [to] be guilty of the grossest negligence," and that they defeated the purposes of the general law which imposed duties in the conduct of corporate affairs. Bonsw of Trade, Report of Codrpany Law Axrendarent Coararrtee, 1925-26, at 19. Parliament responded by prohibiting indemnity agreements favoring company directors or independent auditors. Companies Act, 1929, 19 \& 20 Geo. 5, c. 23, § 152, embodied in Companies Act, 1948, 11 \& 12 Geo. 6, c. 38, § 205, 6 Hatsbury, Laws of ENGLANd $\$ 621$ (3d ed. 1954), and later extended this policy to debenture trustees, Companies Act, 1948, 11 \& 12 Geo. 6, c. 38, §88(1), 6 HALSBURY, stpra. at $\$ 906$.

39. McCourt v. Singers-Bigger, 145 F. 103, 114 (8th Cir. 1906); Apfel v. Auditore, 223 App. Div. 457, 228 N.Y. Supp. 489 (1928), aff'd mem., 250 N.Y. 600,166 N.E. 339 (1929) ; Hollander v. Breeze Corps., 131 N.J. Eq. 585, 26 A.2d 507 (1941), aff'd per curian, 131 N.J. Eq. 613, 26 A.2d 522 (1942). See Washington, Litigation Expenses of Corporatc Directors in Stockholders' Suits, 40 Coluar. L. Rev. 431, 433 (1940); Bishop, Current Status of Corporate Directors' Right to Indemnification, 69 HARv. L. REv. 1057, 1060 (1956).

40. McConnell v. Combination Min. \& Mfill Co., 31 Mront. 563, 572, 79 Pac. 248 (1905).

41. The purchaser can sell his stock before recovery, § 11 (c) (2), 48 Stat. 83 (1933), 15 U.S.C. $\S 77 \mathrm{k}(\mathrm{e})(2)(1958)$, thereby immunizing himself from the effect of any indemnification, but even if he chose to retain the security, the effect of indemnifieation on his investment would generally be insignificant.

42. 3 Loss 1835. 
seem justified in acting on this theory; Congress specifically considered such fears in $1934,{ }^{43}$ and passed two amendments to Section 11. The first lowers the standard of care of persons other than issuers from "that required of a person occupying a fiduciary relationship" 44 to "that required of a prudent man in the management of his own property." 45 The second lessens the duty ${ }^{46}$ of persons other than the issuer to verify statements made on the authority of an expert; those persons, other than the expert himself, must discharge a negative burden - that they had no reasonable ground to disbelieve the statements ${ }^{47}$ rather than the positive burden applying to all other statements in the registration statement and prospectus. But there is no indication that Congress intended further to relieve underwriters of their statutory duty. Moreover, Section 11 liability has not been as drastic as its critics predicted.98

The arguments which indicate that indemnity agreements are contrary to the policy of the Securities Act would apply with equal force to insurance contracts. ${ }^{49}$ Arguably, however, current practices of underwriting insurance may not have the same effect on the prophylactic policy of Section 11 as indemnity agreements. Premiums for such policy are high; thus underwriters frequently do not or cannot obtain coverage to the full extent of the issue. Even more important, it is probable that insurance for subsequtent issues would be more expensive or more difficult to obtain after an underwriter was found liable under Section 11. Indemnity clauses in underwriting agreements, on the other hand, would seem to be readily available to the underwriter without significant increase in the price he pays for the securities to be issted. This will be especially true where a contract is negotiated between a large underwriter and a small unsophisticated issuer, the situation in which the maintenance of high standards of investigation by the underwriter is most in the public interest.

43. Id. at 1727.

44. Section 11 (c), 48 Stat. 83 (1933).

45. 48 Stat. 907 (1934), 15 U.S.C. $77 \mathrm{k}$ (c) (1958).

46. See $\$ 11$ (b) (3) (C), 48 Stat. 83 (1933).

47. 48 Stat. 907 (1934), 15 U.S.C. $77 \mathrm{k}(\mathrm{b}) 3$ (C) (1958).

48. See 3 Loss 1684 ; note 36 supra.

49. The choice of policy goals - whether the essential purpose of the liability imposed is to prevent the breach of duty or to compensate the injured party-also seems to be the conttrolling factor here. Thus insurance against liability for murder, Burt v. Union Central Life Ins. Co., 187 U.S. 362, 365-66 (1902), and rape, Haser v. Maryland Casualty Co., 53 N.W.2d 508 (N.D. 1952), has been held void as tending to "encourage an abatement of the laws," id. at 512. But where a state statute required automobile liability insurance, thereby enunciating a public policy that compensation to injured persons was the dominant goal of liability, it was held that an insurance policy covering willful injury was not vold, though at common law it would not have been upheld, Wheeler v. O'Connell, 297 Mass. $549,554,9$ N.E.2d 544, 547 (1937). The cases upholding insurance for negligence liability, supra note 24 , rest on the assumption that compensation is the dominant goal; where public policy is demonstrably that prevention of breach of duty is more important than compensation, the validity of insurance contracts may be questioned.

50. Practicing Law Institute, op. cit. silpra note 7, at 84. 